\title{
Optimizing Energy Use, Cost and Carbon Emission through Building Information Modelling and a Sustainability Approach: A Case-Study of a Hospital Building
}

\author{
Shabir Hussain Khahro ${ }^{1, *}$, Danish Kumar ${ }^{2}$, Fida Hussain Siddiqui ${ }^{3}{ }^{\circledR}$, Tauha Hussain Ali ${ }^{2}$, \\ Muhammad Saleem Raza ${ }^{2}$ and Ali Raza Khoso ${ }^{4}$ (D) \\ 1 Department of Engineering Management, College of Engineering, Prince Sultan University, 11586 Riyadh, \\ Saudi Arabia \\ 2 Department of Civil Engineering, Mehran University of Engineering and Technology, Jamshoro 76062, Sindh, \\ Pakistan; danish15ce71@gmail.com (D.K.); pvc@admin.muet.edu.pk (T.H.A.); \\ msaleemraza43@gmail.com (M.S.R.) \\ 3 Department of Civil and Construction Engineering, Swinburne University of Technology, Melbourne, \\ VIC 3122, Australia; fsiddiqui@swin.edu.au \\ 4 Department of Structure and Materials, Faculty of Engineering, School of Civil Engineering, Universiti \\ Teknologi Malaysia (UTM), Johor Bharu 81310, Malaysia; raza.ali@graduate.utm.my \\ * Correspondence: shkhahro@psu.edu.sa
}

\section{check for} updates

Citation: Khahro, S.H.; Kumar, D.; Siddiqui, F.H.; Ali, T.H.; Raza, M.S.; Khoso, A.R. Optimizing Energy Use, Cost and Carbon Emission through Building Information Modelling and a Sustainability Approach: A Case-Study of a Hospital Building. Sustainability 2021, 13, 3675.

https://doi.org/10.3390/su13073675

Academic Editor:

Ali Bahadori-Jahromi

Received: 15 February 2021

Accepted: 19 March 2021

Published: 25 March 2021

Publisher's Note: MDPI stays neutral with regard to jurisdictional claims in published maps and institutional affiliations.

Copyright: (C) 2021 by the authors Licensee MDPI, Basel, Switzerland This article is an open access article distributed under the terms and conditions of the Creative Commons Attribution (CC BY) license (https:// creativecommons.org/licenses/by/ $4.0 /)$.

\begin{abstract}
The construction industry (CI) has a significant impact on the environment and on climate change due to the emission of greenhouse gases like carbon dioxide. Globally accepted Sustainable Development Goals (SDG), specifically SDG 7 (Access to Affordable, Reliable, Sustainable and Modern Energy for All), SDG 9 (Industry, Innovation and Infrastructure), and SDG 11 (Sustainable Cities and Communities) stress the responsible utilization of energy in various industries, including construction. The CI uses almost half of the world's produced energy. Therefore, this research presents insights into the efficient use of energy in the building sector and shows how energy efficiency can be achieved by altering different parameters and components like orientation, materials, glazing, and HVAC systems through a case study of a hospital building in Green Building Studio (GBS). This paper also aims to use the Building Information Modelling (BIM) approach to make environmentally sustainable decisions to reduce energy waste in projects. Initially, beneficial factors of BIM on green buildings were identified in the literature and later ranked, based on expert opinions collected using a set of questionnaires. Average Index was used for data analysis. The identified benefits were validated by conducting energy analyses on a hospital model through 3D BIM. It was concluded that a substantial share of energy cost, carbon dioxide $\left(\mathrm{CO}_{2}\right)$, and electricity can be saved using this approach. It was determined that a quick and sustainable design process, improved energy efficiency, enhanced building performance, and provision of better design alternatives are the key benefits of the adoption of BIM by such projects. A Cronbach's alpha value of 0.822 was obtained, which further validates the results. The proposed approach may lead future structures to be sustainable and enriches the culture of energy-efficient green buildings.
\end{abstract}

Keywords: carbon emissions; green buildings; green energy; green building studio; sustainable development

\section{Introduction}

The architecture, engineering, and construction (AEC) industry has been a big contributor to environmental pollution, producing tons of waste and carbon emissions. The construction industry (CI) produces $50 \%$ of landfill wastes and is responsible for around $40 \%$ of the pollution detected in drinking water. It causes around $23 \%$ of air pollution [1], and uses $40 \%$ of the world's energy, mostly in the operation phase, producing a large amount of greenhouse gas emissions. Techniques like prefabrication have been introduced 
to cut carbon emissions and reduce waste. Additionally, green and zero-energy buildings are being built to counter the adverse effects of $\mathrm{CI}$ on climate change. A recent conference was focused solely on the urgency of the issue of greenhouse gas emissions and the adoption of sustainable and green practices [2]. Even in developing countries like Pakistan, people are interested in investing in and availing of the benefits of zero energy buildings [3].

Building Information Modelling (BIM), on the other hand, is not only efficient in sustainability analyses and management, but also has a positive impact on the operation, maintenance, and demolition phases of buildings [4-6]. Some authors have merged BIM and green building concepts, defining the priorities of the Green BIM concept as follows: "to accomplish established sustainability goals by 3D modelling, producing and working with coordinating building data during project life cycle to enhance the efficiency, quality and performance of the building" [4,7]. The reason BIM is being widely used for the construction of green buildings and even traditional buildings is the coordination benefits between project stakeholders like architects, engineers, designers and, most importantly, the client [5]. Better collaboration will ensure better project designs [8]. Additionally, the cost of the project is reduced. The use of BIM for construction projects and more green sustainable buildings has been a major trend in $\mathrm{CI}$ in recent years. Project stakeholders have observed an outstanding relationship between BIM and green buildings [8]. Since the 2010s, firms in the AEC industry have opted to use BIM for their traditional projects and the Green BIM concept for sustainable projects.

Integrated design approaches through BIM are making it beneficial for the design of green buildings [7]. Research is being done on BIM tools that can benefit the design, construction, and operation of green buildings, like software for energy simulations, air analyses, and reuse and recycle analyses of construction waste [4]. Further, Leadership in Energy and Environmental Design (LEED), which gives certification to green sustainable buildings, has some recommendations for the construction of green buildings, like optimizing building mass, green facades, having green vegetated roofs which reuse greywater and control temperatures, and putting lighting sensors to optimize energy consumption [9]. As such, the current research covers some of these aspects by applying changes to the mentioned parameters and reviewing their effects on energy efficiency, resulting in the prospective attainment of the respective Sustainable Development Goals (SDGs). A great deal of research has been conducted to date, e.g., to correlate the attainment of SDGs through building material development and usage [10] and stakeholder management for the effective adaptation of green building concepts in the industry [11]. In a recently conducted study for Chinese CI, the authors investigated the barriers which hinder the adoption of sustainable practices and the attainment of SDGs. The specific objectives of current study include the identification and ranking of BIM factors imparting a positive influence on green buildings and the validation of those benefits through an integrated energy analysis of a case-study 3D BIM model using Green Building Studio (GBS).

\section{AEC, BIM, and Sustainability}

"Sustainable Development" (SD) in the 21st century has emerged as the latest development tag where a wide range of governmental organizations, as well as the nongovernmental agencies, have taken it as the modern mode of development. This includes problems related to the environment and confusion about the concepts of sustainability and participation [12]. Increasing concerns relating to ecology and resources in the 1980s led to the advent of the sustainable development concept, which focused on meeting the needs of present generations without compromising the ability of future generations to meet their own needs, as outlined in the 'Brundtland Report' [13,14]. The construction industry is regarded as the primary consumer of natural raw resources, and hence, the $\mathrm{SD}$ requires $\mathrm{CI}$ to function in a sustainable manner [15]. Initially, the SD only focused on environmental issues, but with the passage of time, SD has come to encompass ethical, 
social, and economic issues. Since then, SD has become an amalgamation of economic, ecological, and social issues [16].

The 2005 World Summit Outcome, drafted by the General Assembly of the United Nations, identified three interdependent components of sustainable development: Economic development, social development, and environmental protection [17]. As the oft-quoted phrase, John Elkington translated this idea: "planet, people and profit," which defines the triple bottom line of greening society [18]. Furthermore, the indicators and targets such as Indicator 7.1.1, Indicator 7.2.1, Target 9.4, and Indicator 11.7.1 of the SDGs (set by United Nations) emphasize for the provision of electricity, increment in renewable energy's share, up-gradation and adoption possibility of the infrastructure facilities to sustainable approaches, and provision of open spaces for public use ultimately for their wellbeing and leading to sustainable development [19-24]. The summarized literature depicts the research literature review's efforts below. It depicts researchers' efforts in different regions of the world for the highlighted SDGs' direct and indirect achievements.

Despite the concept of "environmental sustainability" and "sustainable development" being very well known to the AEC industry for many years, the industry is still considered an infant in terms of controlling and managing carbon emissions and is criticized for being a major carbon emitter [4]. After being hit by disastrous global warming issues, environmental degradation, unexpected climatic changes, the shortage of energy resources, and increasing energy costs, the AEC industry is continuously being pressured to minimize their energy consumption to avoid carbon emissions and tackle the concerns. Therefore, humans in general and the AEC industry have shifted their focus towards the building and development of the low carbon green buildings and environmentally friendly cities $[3,18]$. The green design can be best served through an integrated design process, and BIM is best known for facilitating this. Taking this into account, continuous endeavors are being made in exploring the possibility of BIM in facilitating the development of green buildings. The innovation of BIM technology in green and sustainable buildings has brought some latest means to predict, manage, and monitor the environmental impacts of construction through its virtual prototyping and visualization technology. Due to BIM integration and coordination features with different models like Mechanical, Electrical, and Plumbing (MEP), and architecture; it can enclose and incorporate loads of information within one single model, which helps in efficient analyses of environmental performances and to enhance sustainability measures more precisely [4]. BIM is possibly the best methodology to integrate the analog-energy buildings, airflow analysis, and buildings' sunshine ecosystems. Using BIM helps us reduce energy consumption and construction waste to a greater extent and improve construction quality [25]. With the availability of innovative software like GBS that uses cloud computing technology for different building analyses by gathering data from its nearest weather station. It can perform tasks such as estimation of energy consumptions, production and use of renewable energy, and calculations regarding the building's annual carbon footprint [4].

BIM tools are beneficial in selecting good orientation and moderating other components of the building and result in energy cost and optimization of the building envelope. Techniques like water harvesting to reduce water usage in the building can also be implemented by using BIM in the design stage. The viable options for sustainability design can be studied in a model and geospatial data to locate and import building site information to place it within the context and contribute to an understanding of issues relating to climate, surrounding systems, and resources. The real coordinates then help lessen the impact and utilize the surrounding environment sustainably to reduce energy requirements, such as solar orientation [26], as is done in the current study. BIM tools give the power to see the path of the sun and its shadows on the buildings. Energy can be saved by utilizing more efficient technology to have higher levels of comfort with less cost by using daylight as a primary light source, which helps in reducing building energy demand [27], as artificial lights in buildings consume $18 \%$ of the total energy produced in the world [28]. For example, the facade in office buildings' amount of glass used is more than a residential 
one, so better designs are needed to avoid glaring and thermal discomfort problems. The thermal discomfort can be responsible for extra energy consumption. A proposed solution to minimize the solar gain could be horizontal louvres for the south facade and vertical louvres for the east facade [29].

Furthermore, vegetation is used for shading purposes on the roof, and its effectiveness changes with growing in spring and wilting in winter. In summer, the dense leaf of the plants absorbs the solar radiation and trough evapotranspiration process decreases the air temperatures. In winter, the bare branches of the plants provide the low angle for solar radiation into the interior of the building [30]. BIM software like GBS can calculate the amount of renewable energy production through solar and wind, so their feasibility can be assessed [31-33]. BIM helps designers and engineers choose optimal design schemes balancing carbon emissions, energy, and cost for the client through a multi-objective optimization model [34]. The software also provides water analysis mainly at the design phase by estimating water usage based on relevant factors. They help optimize the water distribution system of buildings of waste products that will be generated at the site [31]. The increasing number of construction activities have multiplied the ill environmental impacts of construction and demolition waste (C\&D) and has become a severe socioenvironmental concern and a political issue. However, with the growing awareness of environmental sustainability, governments and industries are looking towards effective C\&D management practices. For this purpose, practitioners have also been working hard to create BIM-based tools for estimating the waste from the demolitions of buildings [4]. Sustainable construction's aspect of waste reduction can also be achieved through BIM [35]; as researched for Pakistan's CI, BIM and Artificial Intelligence can help in waste reduction and management $[29,30]$.

As mentioned before, the author in $[3,36,37]$ worked out the interests of people in developing countries like Pakistan and their willingness to pay extra for adaptation of net-zero energy buildings. From this study, it is determined that people are willing to pay the price for energy-efficient homes, which can be made possible with integrated concepts like BIM, sustainability, and green building. Furthermore, review and case-based studies have been conducted on the economic sustainability assessment of the residential buildings with BIM [38] for the effective integration of both concepts. In this research paper, the factors have been identified from the research done previously about BIM and energy efficiency of building through BIM. However, there was a lack of practical approach in those research papers which is considered in this work with energy analysis through GBS and its savings in carbon emissions, energy, and its cost by doing several alternatives, as explained further below. BIM and its beneficial relationship with green buildings have been well established in the literature, and the relevant factors are summarized below in Table 1. Identified factors were later utilized in the questionnaire survey.

Table 1. Benefits of Building Information Modelling (BIM)-based modelling approaches.

\begin{tabular}{ccc}
\hline S. No. & Benefits of BIM & Sources/References \\
\hline 1. & Enhanced Building Performance & {$[4,5,25,39-41]$} \\
2. & Improved Energy Efficiency & {$[4,5,25,39-44]$} \\
3. & Quick and Sustainable Design Process & {$[4,5,25,41,44-47]$} \\
4. & Provision of Better Design Alternatives & {$[4,5,25,41,44,47]$} \\
5. & Viable Options for Low Carbon Footprint & {$[5,47]$} \\
6. & Carbon Saving during Building Operation & {$[5]$} \\
7. & Construction Waste Reduction & {$[5,41,43]$} \\
8. & Calculations of Water Availability and Usage & {$[5,43]$} \\
9. & Estimation of Grey Water Reuse Potentials & {$[42]$} \\
10. & Quantification of Rainwater Harvesting Systems & {$[5,25,43]$} \\
11. & Green Innovation and Supply Chain Collaboration & {$[5,39,40,45,47]$} \\
\hline
\end{tabular}


Table 1. Cont.

\begin{tabular}{ccc}
\hline S. No. & Benefits of BIM & Sources/References \\
\hline 12. & Improved Facility Management & {$[5,39,40,44,45]$} \\
13. & Better Project Definition & {$[5,41]$} \\
14. & LCA of Energy, Water, and Fuel Usage & {$[5,41]$} \\
15. & Estimation of Potential Green Energy Production & {$[41,45,48]$} \\
16. & n-Dimensional Visualization & {$[4,5,25,39,40,46,48]$} \\
17. & Efficient Procurement of Materials & {$[5,41,43]$} \\
\hline
\end{tabular}

\section{Research Methodology}

Following the approach by authors in [49] for buildings energy and carbon emission analysis in the operational phase, a multi-step methodology was adopted, as shown in Figure 1. In the initial phase, journal articles, conference proceedings, books, and reports were attained from various scientific databases. Obtained documents were then scanned for beneficial factors concerning the integration of BIM in green buildings. After the literature mapping of these factors (benefits), interviews were conducted with the industry experts related to BIM to verify their existence with Pakistan's CI. In the next phase, factors were assembled in a questionnaire format which consisted of two parts: Demographics of construction personnel and benefits of BIM integration in green buildings. The perceptions of construction sector practitioners were acquired through the questionnaire. They were asked to rank the factors on a five-point Likert scale ranging from strongly disagree to strongly agree. Data Analysis was performed using SPSS version 24 to obtain the topmost significant factors based on Average Index (AI) value obtained for each factor. In the third phase, a case study model was prepared for a hospital to know the ranked factors' validity through energy analysis. The analysis was done by designing a Autodesk RevitAutodesk Revit model and exporting that in gbXML format to GBS. The case-study hospital building's exact location is provided as an input to GBS to fetch the data from the nearest weather station for accurate energy analysis. The top ranked factors were validated by different trials conduction on the GBS platform. In the end, conclusions were drawn, and recommendations were put forward, followed by the future research gaps.

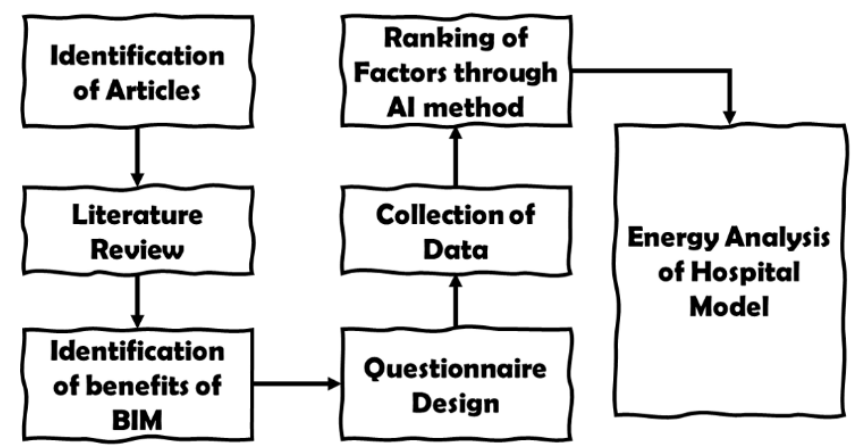

Figure 1. Research methodology flowchart.

\subsection{Questionnaire}

In this study, a structured questionnaire was used to collect data. A well-drafted questionnaire was prepared to seek the opinions of relevant construction practitioners of the country. The first part focused on knowing the education level, positions, experience, type of organization, types, and size of projects, while the second part urged the respondents to rank the BIM-related factors influencing green buildings.

\subsection{Likert Scale}

A five-anchored point Likert scale explained in Table 2 was used in this research. 
Table 2. Likert scale description.

\begin{tabular}{cc}
\hline Values & Description \\
\hline 1 & Strongly Disagree \\
2 & Disagree \\
3 & Undecided \\
4 & Agree \\
5 & Strongly Agree \\
\hline
\end{tabular}

\subsection{Average Index Method}

SPSS version 24 was used to calculate average indices of factors mentioned in a questionnaire so that the significance of each factor can be observed and judged. The AI Formula (1) was adopted from similar factors' identification and ranking studies [43,45].

$$
\mathrm{AI}=\frac{\sum(5 n 1+4 n 2+3 n 3+2 n 4+1 n 5)}{\sum(n 1+n 2+n 3+n 4+n 5)}
$$

where:

$n \mathbf{1}=$ Count of respondents for scale 1 ;

$n \mathbf{2}=$ Count of respondents for scale 2;

$n 3=$ Count of respondents for scale 3 ;

$n 4=$ Count of respondents for scale 4 ;

$n 5=$ Count of respondents for scale 5 ;

$(n 1+n 2+n 3+n 4+n 5)=$ Total respondents.

\subsection{Model Development}

Autodesk Revit was used to develop the model for energy analysis on GBS. The model of the hospital was developed after the consultation of the stakeholders. The architectural, structural, and MEP model was developed on Autodesk Revit. The model was exported in gbXML format from Autodesk Revit, which is a required data exchange format for analysis on GBS. The hospital model is designed with Level of Detail (LOD) 300 and by looking at structural safety and sustainability practices. The building has a gross floor area of 3562.6 $\mathrm{m}^{2}$ and a base floor area of $815.65 \mathrm{~m}^{2}$. Keeping these principles in mind, the model was designed with a structural framing system made up from concrete, which amounts to 1334.981 cubic meters. The recyclable bricks were used to construct walls, as such bricks are sustainable in the long run and can be recovered, reused, and recycled for new projects [50]. Figure 2 shows the steps which were followed for the model development. GBS, which is a cloud-based software, uses data from the nearest weather station for energy analysis. The carbon emission calculations are based upon the onsite material and energy use, the source of production of electricity which is to be used during the operational phase, and it can be based on fossil fuels or renewables. A higher percentage of carbon emissions shows that electricity production used for that project is based majorly on fossil fuels. The project considered in this research work is in Hyderabad, Pakistan, where the peak temperatures are around $45^{\circ} \mathrm{C}$ in summer. The same temperatures were used by GBS for analysis. Rates used for calculation of cost were taken from local energy suppliers in Hyderabad which are set by the government for the hospital buildings. 




Figure 2. Process flow chart of model development.

\section{Results and Discussion}

\subsection{Response Rate}

The survey was conducted through Google forms, emails, and by hand. Forty-four number questionnaires were distributed, and 30 valid responses were obtained from industry professionals, making the response rate $68 \%$ for the acquired data. The lower response rate is due to the fact, pointed out in the literature [51,52], that there is very low awareness about green buildings in developing countries. Moreover, the study [3] also claimed that only 28.6 percent of respondents were aware of the green buildings phenomenon in Pakistan, and hence, the lower response rate was unavoidable.

\subsection{Demographics of Respondents}

The respondents' demographics include education level, positions, experience, type of organization types, and size of projects, as detailed below.

\subsubsection{Working Position of Respondents}

The position of respondents in their respective organizations is shown below. The respondents had various posts in their organizations, such as CEOs, Directors, project managers, site engineers, academics, and others, as represented in Figure 3.

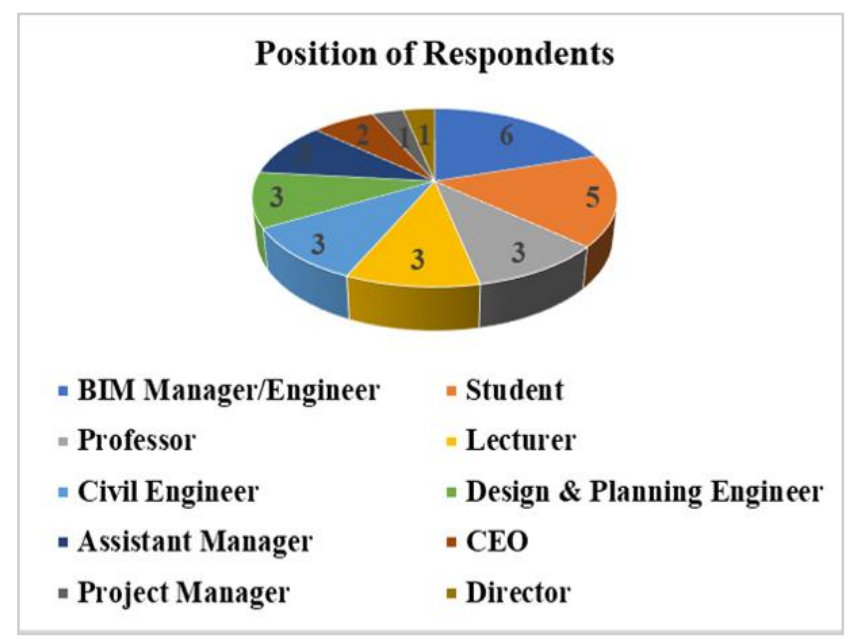

Figure 3. Position of respondents. 


\subsubsection{Types of Projects}

The survey respondents with industry professional experience had undertaken various projects such as buildings, infrastructures, build-infrastructures, etc., as shown in Figure 4.

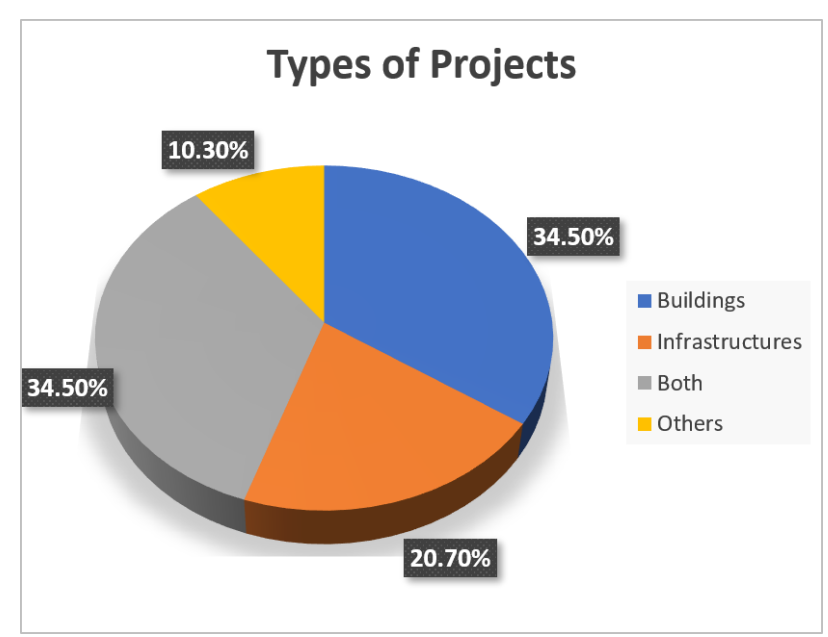

Figure 4. Types of projects.

\subsection{Reliability of Collected Data}

Cronbach's Alpha value determines the reliability of the collected data. The value indicates the internal consistency of the set of items. Hence, it can be concluded that the higher values of Cronbach's alpha denote greater consistency and reliability in data. The alpha values ranging from 0.7 to 0.95 are considered highly acceptable values [46]. For the present research, the obtained value of Cronbach's alpha is presented in Table 3.

Table 3. Reliability statistics.

\begin{tabular}{cc}
\hline Cronbach's Alpha & No. of Items \\
\hline 0.822 & 17 \\
\hline
\end{tabular}

\subsection{Ranking Factors}

The use of BIM technology for the construction of green buildings is quite beneficial. In the questionnaire form, the respondents were asked to rank the factors of BIM imparting positive impacts on green construction. The factors are presented in Table 4. Along with rank and AI value of each factor.

Table 4. Ranking of BIM factors. AI: Average Index.

\begin{tabular}{ccc}
\hline Rank No. & Factor & AI \\
\hline 1. & Quick and Sustainable Design Process & 4.4828 \\
2. & Improved Energy Efficiency & 4.4483 \\
3. & Enhanced Building Performance & 4.3448 \\
4. & Provision of Better Design Alternatives & 4.3103 \\
5. & n-Dimensional Visualization & 4.2759 \\
6. & Improved Facility Management & 4.2414 \\
7. & Green Innovation and Supply Chain Collaboration & 4.1724 \\
8. & Better Project Definition & 4.1379 \\
9. & Construction Waste Reduction & 4.1034 \\
10. & LCA of Energy, Water, and Fuel Usage & 3.9655 \\
11. & Calculations of Water Availability and Usage & 3.8621 \\
\hline
\end{tabular}


Table 4. Cont.

\begin{tabular}{ccc}
\hline Rank No. & Factor & AI \\
\hline 12. & Quantification of Rainwater Harvesting Systems & 3.7586 \\
13. & Carbon Saving during Building Operation & 3.6552 \\
14. & Estimation of Grey Water Reuse Potentials & 3.6207 \\
15. & Viable Options for Low Carbon Footprint & 3.3448 \\
16. & Estimation of Potential Green Energy Production & 3.3437 \\
17. & Efficient Procurement of Materials & 3.3432 \\
\hline
\end{tabular}

It can be seen from the ranking factors that the majority of these correlate and link to the sustainability aspects of the building, resulting in improved efficiencies, better design provisions, economical and green alternatives for the buildings, carbon savings, and resources' reusability potential and waste reduction aspects, which ultimately lead to the attainment of the SDGs. The top position is acquired by the factor that BIM helps in making the design process sustainable.

\subsection{Conceptual Framework of the Proposed Case Study}

Today, various software are developed that can be used by industry professionals at any stage of construction. BIM provides the platforms to design 3D models and store information utilized in different stages of design, construction, and operational phase. Using the BIM-based software programs and by utilizing the information present in those models, we can make informed decisions and can alter the designs, improve their accuracy, identify the conflicts, and avoid them to get more predictable results.

Typically, construction projects are conventionally executed after thorough planning. Still, due to recent environmental threats, new approaches are needed to optimize the use of resources during the planning and design phases. It is highly recommended in the United Nations' SDGs to design new trends to save natural resources depletion. This study proposes a solution that can be integrated during the construction industry project's design phase to achieve various benefits mentioned in earlier sections. This model incorporates the various indicators considered in sustainable structures, green buildings, and SDG 7 during the building design phases. Now, it is evident that conventional building design approaches cannot integrate all the indicators. Therefore, this study provides an integrated approach between these tools, sustainability indicators, and green building concepts. Figures 5 and 6 show the complete conceptual framework.

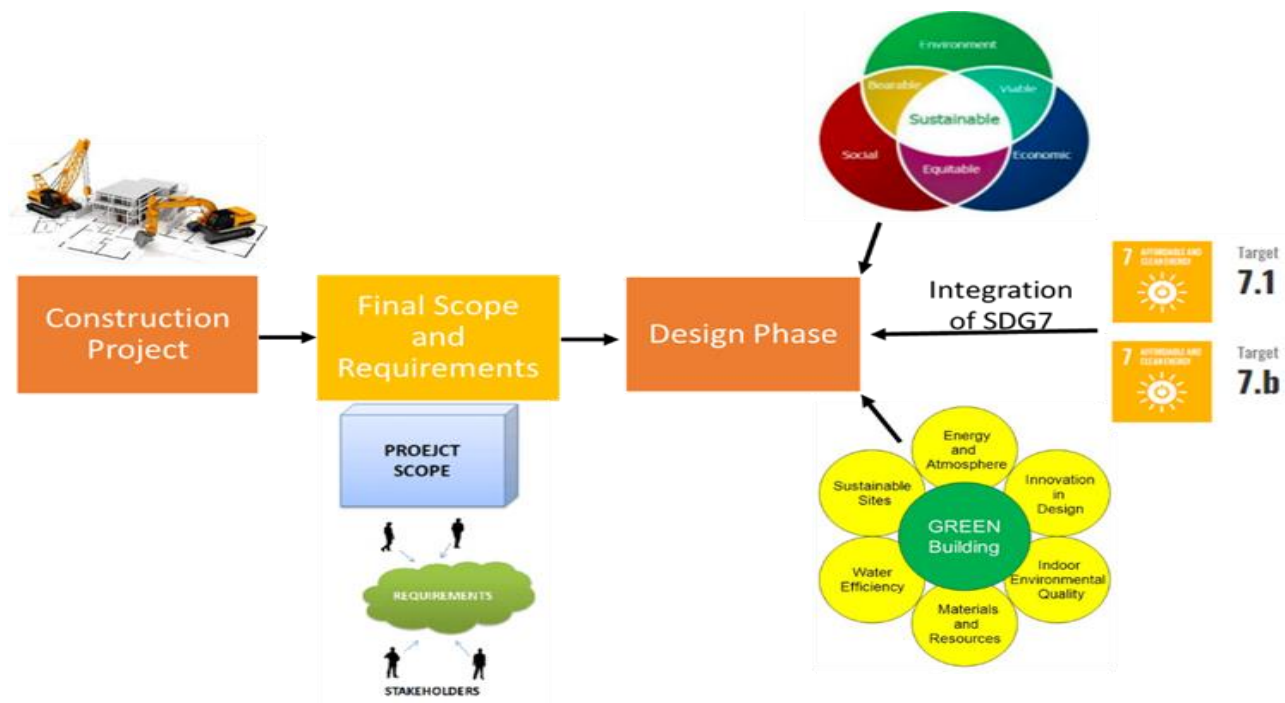

Figure 5. Elementary phase of the planning. 


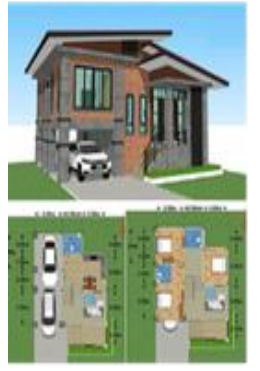

Previous Modelling Approach

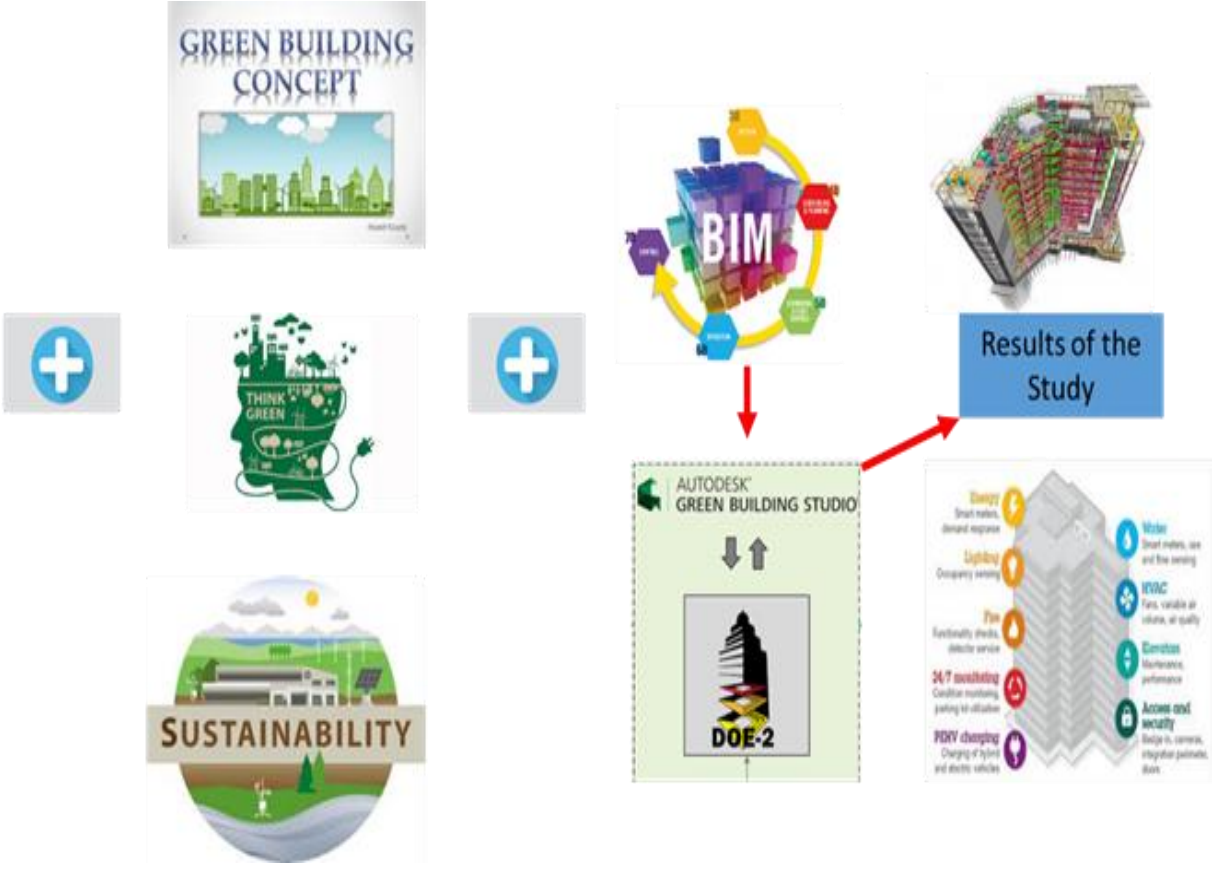

Figure 6. Case study conceptual framework.

This approach will improve the design part of the construction project activities, and the $3 \mathrm{D}$ visualization will make it more user-friendly to modify as per client needs. This study proposes a smart solution to optimize the natural resources in upcoming construction projects. The solution, if applied, can save energy, cost of living, and be a sustainable solution. The targets SDG 7.1 and SDG 7b can be significantly contributed to by this model.

\subsection{Developed Building Models}

The primary 2D model drawing was transformed into 3D in Revit, and the different constructional elements are added in the whole model, as an example, the structural model is shown in Figure 7.

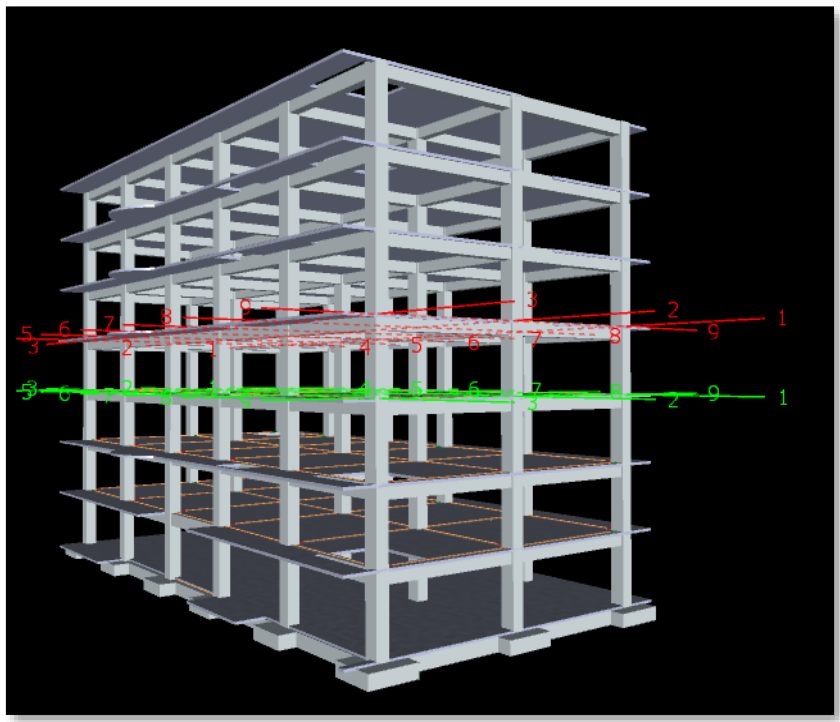

Figure 7. Structural model in Revit. 
The model shows the complete structural key elements of the building, and appropriate sections are also added in the model. Similarly, the whole Mechanical Electrical and Plumbing (MEP) model was created, and the complete drawing is shown in Figure 8.

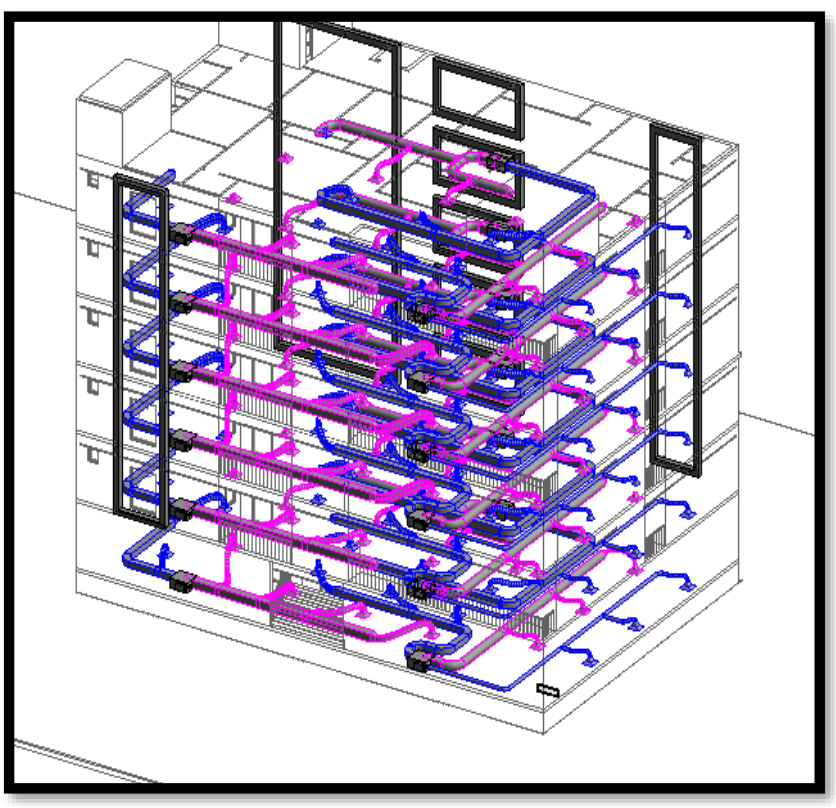

Figure 8. Mechanical Electrical and Plumbing (MEP).

In the next phase, the complete rendering has been done for the building where ventilation and sunlight are the key elements with other secondary elements of sustainable and green buildings, as shown in Figure 9.



Figure 9. 3D rendered exterior view of hospital model.

The model developed after the integration of all models is shown in Figure 10. The cross-sectional elevation shows the different services and utility details.

These models and relevant data were utilized later for the energy, carbon emission, and cost analyses in GBS. The results are mentioned in the next section with a comparative assessment with the conventional method to analyze the difference in both approaches. 


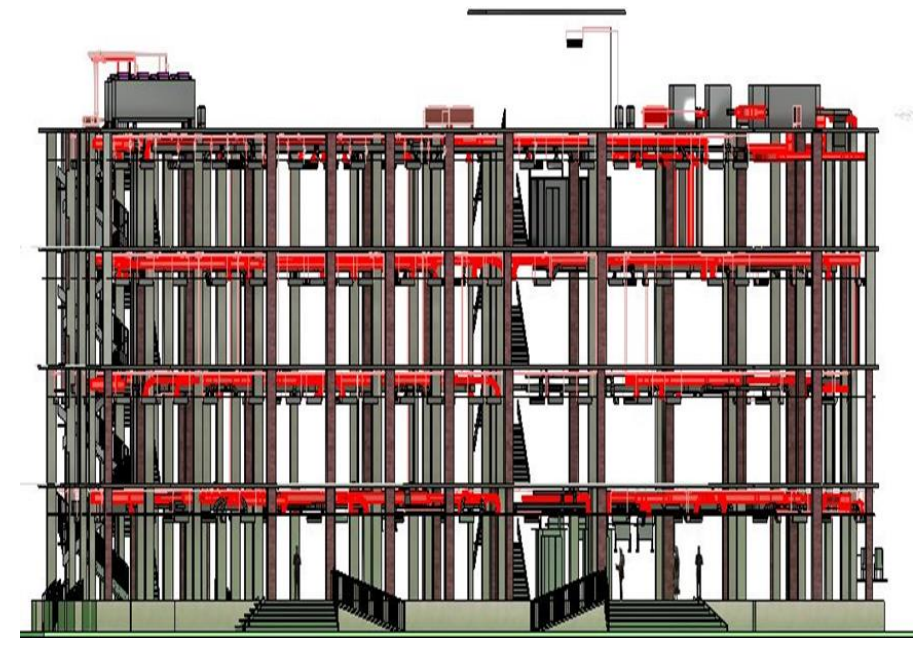

Figure 10. 3D integrated view of structure and MEP.

\subsection{Optimization and Energy Analysis}

Combining BIM with specialized energy modeling software, every part of a building, from MEP systems and orientation elements to interior comfortability elements, can be simulated and optimized for energy efficiency. The top 5 ranking factors were analyzed on a hospital model. Its energy use was calculated along with carbon emissions of the building, which helps to reduce the cost of the project and make effective changes in the design. In GBS, a total of thirteen trials were run on the model. Table 5 contains the results of different trials, which shows the building type, which was analyzed, along with the floor area of the model, annual electric cost, and annual fuel cost of the hospital building according to local rates. Moreover, annual electric use in KWh and annual fuel use in MJ are provided for different trials and base runs without any changes in the model. Further, the energy use intensity of the building is provided. The results also contain the amount of carbon emissions of the building with different trials, which is an important aspect to be considered because $\mathrm{CI}$ is a big contributor to carbon emissions in the environment. The amount of carbon emissions in tons per year that can be saved is mentioned as well.

Several trials were based on changing the building's orientation up to 15 degrees, and changes were observed in the model along with better airflow and reduced energy use. When changes in orientation and low emission glazing on windows, daylighting sensors, and the HVAC system were done, it reduced energy use and saved up to 32 tons in carbon emissions. In some trials, framing and wooden insulation frames were also used on windows of the building to reduce the amount of heat entering the building. Additionally, it can be observed in Table 5 that one trial resulted in an increase in carbon emissions as well. Figure 11 shows the comparison of the results between the base run and the best alternative design. 
Table 5. Results from Green Building Studio (GBS).

\begin{tabular}{|c|c|c|c|c|c|c|c|c|c|c|}
\hline $\begin{array}{l}\text { S. } \\
\text { No. }\end{array}$ & $\begin{array}{l}\text { Design } \\
\text { Alterna- } \\
\text { tives }\end{array}$ & $\begin{array}{c}\text { Building } \\
\text { Type }\end{array}$ & $\begin{array}{l}\text { Floor } \\
\text { Area } \\
\left(\mathrm{m}^{2}\right)\end{array}$ & $\begin{array}{c}\text { Annual } \\
\text { Electric } \\
\text { Cost } \\
\text { (Rs) }\end{array}$ & $\begin{array}{c}\text { Annual } \\
\text { Fuel } \\
\text { Cost } \\
\text { (Rs) }\end{array}$ & $\begin{array}{l}\text { Annual } \\
\text { Electric } \\
\text { Use } \\
\text { (KWh) }\end{array}$ & $\begin{array}{c}\text { Annual } \\
\text { Fuel Use } \\
\text { (MJ) }\end{array}$ & $\begin{array}{l}\text { Energy Use } \\
\text { Intensity } \\
\left(\mathrm{MJ} / \mathrm{m}^{2} / \text { year) }\right.\end{array}$ & $\begin{array}{l}\text { Carbon } \\
\text { Emis- } \\
\text { sions } \\
\text { (Tons) }\end{array}$ & $\begin{array}{l}\text { Carbon } \\
\text { Emis- } \\
\text { sion } \\
\text { Saved } \\
\text { (Tons) }\end{array}$ \\
\hline 1 & $\begin{array}{l}\text { Thesis } \\
\text { GBxml.xml } \\
\text { (Base Run) }\end{array}$ & Hospital & 815.65 & $\begin{array}{c}3.24 \times \\
10^{6}\end{array}$ & $\begin{array}{c}5.29 \times \\
10^{4}\end{array}$ & $\begin{array}{c}2.16 \times \\
10^{5}\end{array}$ & $\begin{array}{c}9.29 \times \\
10^{4}\end{array}$ & 1067.40 & 114.20 & \\
\hline 2 & $\begin{array}{l}15^{\circ} \text { VAV } \\
\text { Gas Boiler }\end{array}$ & Hospital & 815.65 & $\begin{array}{c}2.94 \times \\
10^{6}\end{array}$ & $\begin{array}{c}5.88 \times \\
10^{4}\end{array}$ & $\begin{array}{c}1.96 \times \\
10^{5}\end{array}$ & $\begin{array}{c}1.03 \times \\
10^{5}\end{array}$ & 991.58 & 104.20 & 10.00 \\
\hline 3 & $\begin{array}{c}30^{\circ} \text { low E } \\
\text { with gas } \\
\text { boiler }\end{array}$ & Hospital & 815.65 & $\begin{array}{c}2.99 \times \\
10^{6}\end{array}$ & $\begin{array}{c}5.69 \times \\
10^{4}\end{array}$ & $\begin{array}{c}1.99 \times \\
10^{5}\end{array}$ & $\begin{array}{c}1.00 \times \\
10^{5}\end{array}$ & 1002.82 & 105.80 & 8.40 \\
\hline 4 & $\begin{array}{l}15^{\circ} \text { change } \\
\text { in orienta- } \\
\text { tion }\end{array}$ & Hospital & 815.65 & $\begin{array}{c}3.24 \times \\
10^{6}\end{array}$ & $\begin{array}{c}5.28 \times \\
10^{4}\end{array}$ & $\begin{array}{c}2.16 \times \\
10^{5}\end{array}$ & $\begin{array}{c}9.29 \times \\
10^{4}\end{array}$ & 1067.58 & 114.20 & 0.00 \\
\hline 5 & $\begin{array}{l}180^{\circ} \text { with } \\
\text { low E } \\
\text { glazing }\end{array}$ & Hospital & 815.65 & $\begin{array}{c}3.24 \times \\
10^{6}\end{array}$ & $\begin{array}{c}5.29 \times \\
10^{4}\end{array}$ & $\begin{array}{c}2.16 \times \\
10^{5}\end{array}$ & $\begin{array}{c}9.30 \times \\
10^{4}\end{array}$ & 1067.64 & 114.20 & 0.00 \\
\hline 6 & $\begin{array}{l}15^{\circ} \text { PVAV } \\
\text { econo- } \\
\text { mizer low } \\
\text { E }\end{array}$ & Hospital & 815.65 & $\begin{array}{c}3.27 \times \\
10^{6}\end{array}$ & $\begin{array}{c}6.19 \times \\
10^{4}\end{array}$ & $\begin{array}{c}2.18 \times \\
10^{5}\end{array}$ & $\begin{array}{c}1.09 \times \\
10^{5}\end{array}$ & 1095.53 & 116.07 & -1.87 \\
\hline 7 & $\begin{array}{l}15^{\circ} \mathrm{VAV} \\
\text { Under- } \\
\text { floor air } \\
\text { distribu- } \\
\text { tion } \\
2\end{array}$ & Hospital & 815.65 & $\begin{array}{c}2.27 \times \\
10^{6}\end{array}$ & $\begin{array}{c}7.23 \times \\
10^{4}\end{array}$ & $\begin{array}{c}1.52 \times \\
10^{5}\end{array}$ & $\begin{array}{c}1.27 \times \\
10^{5}\end{array}$ & 825.30 & 82.20 & 32.00 \\
\hline 8 & $\begin{array}{l}15^{\circ} \text { PVAV } \\
\text { Gas Boiler } \\
\text { with } \\
\text { sensors }\end{array}$ & Hospital & 815.65 & $\begin{array}{c}3.23 \times \\
10^{6}\end{array}$ & $\begin{array}{c}5.97 \times \\
10^{4}\end{array}$ & $\begin{array}{c}2.15 \times \\
10^{5}\end{array}$ & $\begin{array}{c}1.05 \times \\
10^{5}\end{array}$ & 1079.30 & 114.53 & -0.33 \\
\hline 9 & $\begin{array}{c}15^{\circ} \text { VAV } \\
80 \% \text { gas } \\
\text { boiler with } \\
\text { daylight } \\
\text { sensors }\end{array}$ & Hospital & 815.65 & $\begin{array}{c}3.10 \times \\
10^{6}\end{array}$ & $\begin{array}{c}6.08 \times \\
10^{4}\end{array}$ & $\begin{array}{c}2.07 \times \\
10^{5}\end{array}$ & $\begin{array}{c}1.07 \times \\
10^{5}\end{array}$ & 1043.81 & 110.10 & 4.10 \\
\hline 10 & $\begin{array}{c}\text { VAV with } \\
\text { metal } \\
\text { frame }\end{array}$ & Hospital & 815.65 & $\begin{array}{c}2.86 \times \\
10^{6}\end{array}$ & $\begin{array}{c}6.23 \times \\
10^{4}\end{array}$ & $\begin{array}{c}1.91 \times \\
10^{5}\end{array}$ & $\begin{array}{c}1.10 \times \\
10^{5}\end{array}$ & 975.39 & 101.70 & 12.50 \\
\hline 11 & $\begin{array}{c}\text { PVAV } \\
\text { with low E } \\
\text { glazing }\end{array}$ & Hospital & 815.65 & $\begin{array}{c}3.15 \times \\
10^{6}\end{array}$ & $\begin{array}{c}6.08 \times \\
10^{4}\end{array}$ & $\begin{array}{c}2.10 \times \\
10^{5}\end{array}$ & $\begin{array}{c}1.07 \times \\
10^{5}\end{array}$ & 1057.64 & 111.77 & 2.43 \\
\hline 12 & $\begin{array}{c}15^{\circ} \text { with } \\
\text { metal } \\
\text { frame } \\
\text { insulation }\end{array}$ & Hospital & 815.65 & $\begin{array}{c}2.88 \times \\
10^{6}\end{array}$ & $\begin{array}{c}5.86 \times \\
10^{4}\end{array}$ & $\begin{array}{c}1.92 \times \\
10^{5}\end{array}$ & $\begin{array}{l}1.03 \times \\
10^{5}\end{array}$ & 975.28 & 102.30 & 11.90 \\
\hline 13 & $\begin{array}{c}15^{\circ} \\
\text { Wooden } \\
\text { frame } \\
\text { insulation } \\
\text { VAC } 80 \% \\
\text { gas boiler }\end{array}$ & Hospital & 815.65 & $\begin{array}{c}2.82 \times \\
10^{6}\end{array}$ & $\begin{array}{c}5.92 \times \\
10^{4}\end{array}$ & $\begin{array}{c}1.88 \times \\
10^{5}\end{array}$ & $\begin{array}{c}1.04 \times \\
10^{5}\end{array}$ & 957.67 & 100.10 & 14.10 \\
\hline
\end{tabular}




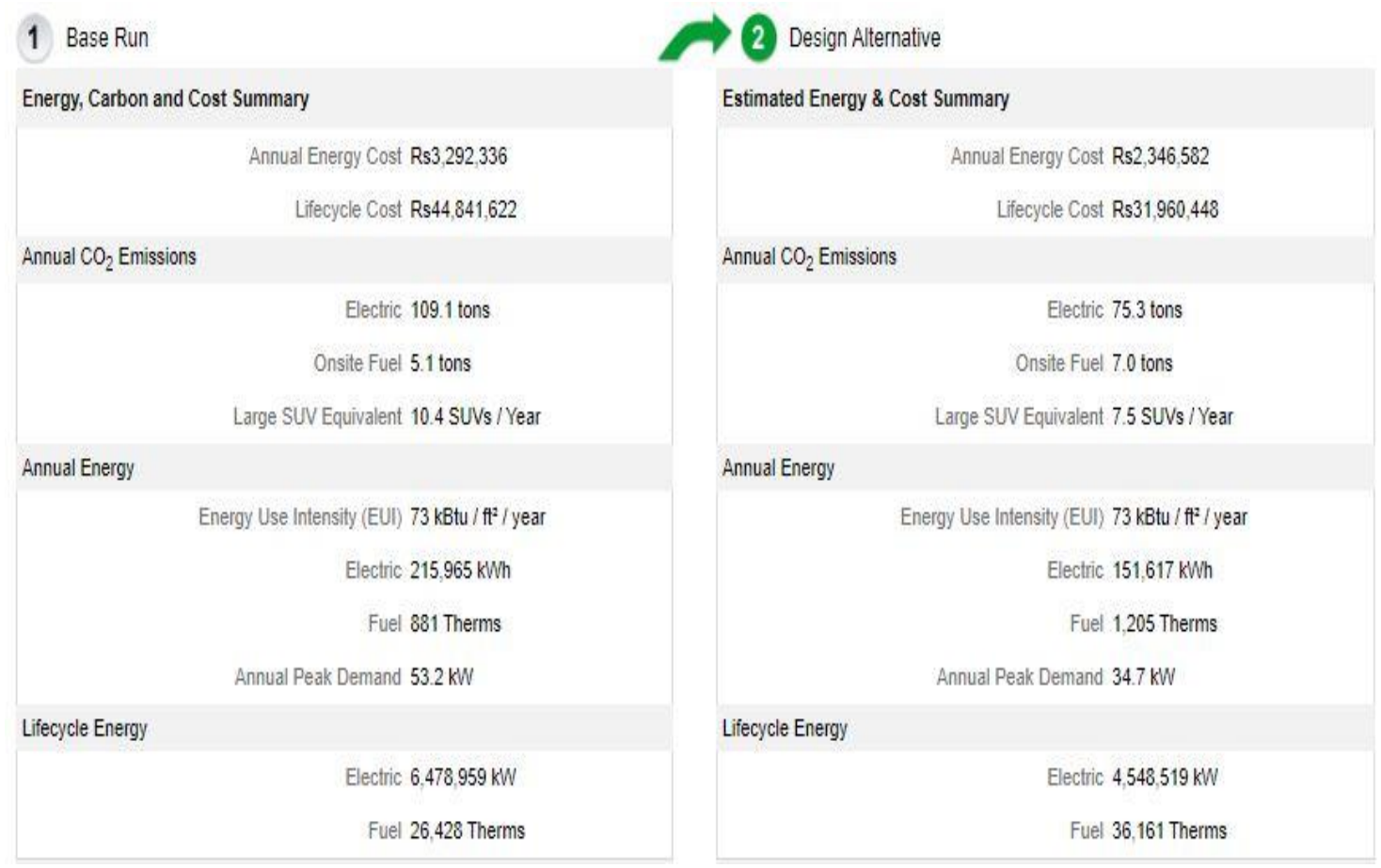

Figure 11. Comparison of results.

The former is without any changes in the building design. The later result is after changing the building's orientation at $15^{\circ}$ with alteration in the HVAC system to the underfloor air distribution system and the use of low emissivity glazing on windows. The glazing allows the visible light to pass through the glass, but reflects the heat, reducing the use of electricity for internal cooling or heating [53]. The authors [54] stated that the underfloor air distribution system is energy efficient and improves the living environment for occupants as well. The best design alternative results also prove the statements that the use of an underfloor air distribution system with low E glazing of windows reduces the energy use and cost significantly. This reduction in energy use also has a major impact on reducing carbon emission. The results show that 32 tons of carbon emission can be achieved by doing these changes. The design alternative to reach the optimum design and energy efficiency can reduce the annual peak demand from 53.2 KW to $34.7 \mathrm{KW}$ and reduce electricity use, as it is costly in a developing country like Pakistan. This reduces annual peak demand and grid electricity use, which can be further reduced by using the PV system on the roof of the building, reducing the carbon emissions further. These interventions also proved effective for annual and lifecycle energy cost. The anticipated annual energy cost after the changes was reduced by almost 1 million rupees, and lifecycle energy cost was reduced by almost 13 million rupees. The summarized optimization results are also represented in Table 6. It is observed from Table 6 that there is a significant saving of resources using the suggested approach mentioned in this paper. 
Table 6. Optimization results.

\begin{tabular}{ccccc}
\hline Feature & Unit & $\begin{array}{c}\text { Conventional } \\
\text { (Ref) }\end{array}$ & Proposed & Saving \\
\hline Annual Energy Cost & PKR & $3,292,336$ & $2,346,582$ & 945,754 \\
Lifecycle Cost & PKR & $44,841,622$ & $31,960,448$ & $12,881,174$ \\
Annual CO Cmissions $_{2}$ & Tons & 114.2 & 82.3 & 31.9 \\
Electric Emissions & Tons & 109.1 & 75.3 & 33.8 \\
Annual Electric Use & $\mathrm{kWh}$ & 215,965 & 151,617 & 64,348 \\
Lifecycle Electric Use & $\mathrm{kWh}$ & $6,478,959$ & $4,548,519$ & $1,930,440$ \\
Annual Peak Demand & $\mathrm{kW}$ & 53.2 & 34.7 & 18.5 \\
\hline
\end{tabular}

\section{Strengths and Limitation of the Research}

A hospital model was selected to perform the case study of reducing the operational energy use and carbon emissions, which account for nearly 85\% [55] of buildings' energy consumption and carbon emissions. A hospital model is chosen, as it is functional and requires constant electricity, fuel, and water for its day-to-day functions. The location for the project is Hyderabad, which has an arid climate and high temperatures during the day. There have not been many significant studies being done on the hot arid climate of Pakistan, especially hospitals in these regions. This study of hospital tries to reduce the building's operational energy in arid climates to achieve sustainability. As for the calculation of carbon emissions during the building's construction phase, values of several coefficients are required, which have not been accurately worked out for the manufacturing and construction industry in Pakistan. Hence, this limits our research to calculating energy use and carbon emissions during the operational phase only. Further validation of only the top five BIM-based benefit indicators was done by performing different GBS trials. Moreover, a realistic approach has been adopted for the cost calculation of energy use. The specific rates for hospitals were obtained from regional service providers for fuel and electricity.

\section{Conclusions and Recommendations}

The present study sought to identify the benefits of BIM-based approaches from the literature, and then the ranking of identified factors was done through collaboration with green building professionals. It is concluded that BIM-based sustainable approaches expedite the design and execution processes at reduced physical and non-physical resources. In particular, the BIM-based approach employed on the hospital model in this study aided in saving the annual electric and fuel cost and reduced carbon emissions.

Though the literature mentions barriers such as lack of skilled personnel, legal and security issues, high cost of implementation, etc., in adopting BIM in developing countries' adoption, specifically in Pakistan [56], BIM has proved its benefits in green building. The use of BIM is very clear in the early design stage. It gives the best results in this stage because of different alternative trials through software such as GBS, and implementing the one that gives the feasible (economical, green, sustainable) results. This study proposes a smart solution to optimize the natural resources in upcoming construction projects. The solution can save energy, costs of living, and be a sustainable solution. It is concluded that a substantial share of cost and electricity can be saved using this approach. This model can significantly contribute to the targets SDG 7.1 and SDG 7b. Based on the results of the study, the following recommendations are suggested.

- The government should take major actions to devise smart systems in the buildings.

- New building and structural codes should be designed to promote energy-efficient buildings.

- The government should introduce a mandatory certification like LEED Green certification to promote smart building concepts.

- The government should provide some incentives and tax relaxation to people and organizations supporting and constructing energy-efficient buildings. 
- Academia and industry should work together to design better cost and time-efficient methods for energy-efficient buildings.

- An independent agency should be formulated to support the idea of smart and energyefficient buildings which will monitor the continuous improvements in the SDG 7, 9, and 11.

Author Contributions: Conceptualization, F.H.S. and Khahro, S.H.K.; methodology, D.K.; software, D.K.; validation, M.S.R.; formal analysis, D.K.; investigation, D.K.; resources, D.K.; data curation, D.K.; writing—original draft preparation, D.K. and S.H.K.; writing—review and editing, A.R.K.; visualization, M.S.R.; supervision, T.H.A.; project administration, T.H.A. All authors have read and agreed to the published version of the manuscript.

Funding: This research received no external funding.

Institutional Review Board Statement: Not Applicable.

Informed Consent Statement: Not Applicable.

Data Availability Statement: Not Applicable.

Acknowledgments: Authors would like to thank the stakeholders, specifically Ali Raza Bhaagat from the Institute of Environmental Engineering and Management, Mehran University of Engineering and Technology, Jamshoro, Pakistan, helped during the data collection phase. The authors are also thankful to Prince Sultan University, Riyadh, Saudi Arabia, for providing financial assistance (Article Processing Charges) and academic support for this publication.

Conflicts of Interest: The authors declare no conflict of interest.



\section{References}

1. Snook, J. How Does Construction Impact the Environment? I GoContractor. Available online: https://gocontractor.com/blog/ how-does-construction-impact-the-environment/ (accessed on 21 June 2017).

2. Passer, A.; Lützkendorf, T.; Habert, G.; Kromp-Kolb, H.; Monsberger, M.; Eder, M.; Truger, B. Sustainable built environment: Transition towards a net zero carbon built environment. Int. J. Life Cycle Assess. 2020, 25, 1160-1167. [CrossRef]

3. Siddiqui, F.; Khoso, A.R.; Ahmed Pathan, A.; Akhund, M.A.; Khahro, S.H. Concept \& Willingness to Adopt Zero Energy Buildings. Indian J. Sci. Technol. 2018, 11, 1-7. [CrossRef]

4. Yang, X.; Hu, M.; Wu, J.; Zhao, B. Building-information-modeling enabled life cycle assessment, a case study on carbon footprint accounting for a residential building in China. J. Clean. Prod. 2018, 183, 729-743. [CrossRef]

5. Wong, J.K.W.; Zhou, J. Enhancing environmental sustainability over building life cycles through green BIM: A review. Autom. Constr. 2015, 57, 156-165. [CrossRef]

6. Lu, Y.; Wu, Z.; Chang, R.; Li, Y. Building Information Modeling (BIM) for green buildings: A critical review and future directions. Autom. Constr. 2017, 83, 134-148. [CrossRef]

7. van Putten, H.P.; Rocha, M.A. Estimating Carbon Dioxide Emission Reduction by Waste Minimization in Civil Construction through the Use of BIM Methodology; CAPES: Oslo, Norway, 2016.

8. Dummenahally, N. Building Information Modeling for Green and Energy Efficient Buildings Design. Int. J. Innov. Sci. Eng. Technol. 2016, 5, 167-170. [CrossRef]

9. Keeler, M.; Vaidya, P. Fundamentals of Integrated Design for Sustainable Building; John Wiley \& Sons: Hoboken, NJ, USA, 2016. 
10. Omer, M.A.; Noguchi, T. A conceptual framework for understanding the contribution of building materials in the achievement of Sustainable Development Goals (SDGs). Sustain. Cities Soc. 2020, 52, 101869. [CrossRef]

11. Zhu, J.; Cao, Y.; Zhai, J.; Zhao, X.; Zhao, Y.; Kang, S. Analysis on synergies and trade-offs in green building development: From the perspective of SDG 11. Chin. J. Popul. Resour. Environ. 2019, 17, 341-351. [CrossRef]

12. Chan, E.H.W.; Qian, Q.K.; Lam, P.T.I. The market for green building in developed Asian cities-The perspectives of building designers. Energy Policy 2009, 37, 3061-3070. [CrossRef]

13. Dania, A.A. Sustainable Construction at the Firm Level: Case Studies from Nigeria; University of Reading: Reading, UK, 2017.

14. Hunter, C. Sustainable tourism as an adaptive paradigm. Ann. Tour. Res. 1997, 24, 850-867. [CrossRef]

15. Kasai, N.; Jabbour, C.J.C. Barriers to green buildings at two Brazilian Engineering Schools. Int. J. Sustain. Built Environ. 2014, 3 , 87-95. [CrossRef]

16. Kuhlman, T.; Farrington, J. What is Sustainability? Sustainability 2010, 2, 3436-3448. [CrossRef]

17. World Health Organization. 2005 World Summit Outcome. 2005. Available online: http://www.who.int/hiv/universalaccess201 0/worldsummit.pdf (accessed on 8 March 2021).

18. Elkington, J. People, Planet, Profit. Available online: https://johnelkington.com/2008/06/people-planet-profit/ (accessed on 8 March 2021).

19. Goal 7: Affordable and Clean Energy_SDG Tracker. Available online: https://sdg-tracker.org/energy (accessed on 27 September 2020).

20. Goal 9: Industry, Innovation and Infrastructure-SDG Tracker. Available online: https://sdg-tracker.org/infrastructureindustrialization (accessed on 27 September 2020).

21. Goal 11: Sustainable Cities and Communities-SDG Tracker. Available online: https://sdg-tracker.org/cities (accessed on 27 September 2020).

22. Cities-United Nations Sustainable Development. Available online: https://www.un.org/sustainabledevelopment/cities/ (accessed on 28 September 2020).

23. Energy-United Nations Sustainable Development. Available online: https://www.un.org/sustainabledevelopment/energy/ (accessed on 28 September 2020).

24. Infrastructure and Industrialization-United Nations Sustainable Development. Available online: https://www.un.org/ sustainabledevelopment/infrastructure-industrialization/ (accessed on 28 September 2020).

25. Bonenberg, W.; Wei, X. Green BIM in Sustainable Infrastructure. Procedia Manuf. 2015, 3, 1654-1659. [CrossRef]

26. Hardin, B.; McCool, D. BIM and Construction Management; Wiley Publishing, Inc.: Hoboken, NJ, USA, 2015 ; ISBN 9781118942765.

27. Sudan, M.; Tiwari, G.N. Daylighting and energy performance of a building for composite climate: An experimental study. Alex. Eng. J. 2016, 55, 3091-3100. [CrossRef]

28. Hua, Y.; Oswald, A.; Yang, X. Effectiveness of daylighting design and occupant visual satisfaction in a LEED Gold laboratory building. Build. Environ. 2011, 46, 54-64. [CrossRef]

29. Hernández, F.F.; Cejudo López, J.M.; Peña Suárez, J.M.; González Muriano, M.C.; Rueda, S.C. Effects of louvers shading devices on visual comfort and energy demand of an office building. A case of study. Energy Procedia 2017, 140, 207-216. [CrossRef]

30. Yan, M.H. Thermal Shading Effect of Climbing Plants on Glazed Facades. In Proceedings of the the 2005 World Sustainable Building Conference, Tokyo, Japan, 27-29 September 2005; pp. 47-54.

31. Liao, C.Y.; Tan, D.L.; Li, Y.X. Research on the Application of BIM in the Operation Stage of Green Building. Appl. Mech. Mater. 2012, 174, 2111-2114. [CrossRef]

32. America, A. The Contractors' Guide to BIM, Las Vegas, USA; AGC Research Foundation: Arlington, VA, USA, 2005.

33. Barnes, S.; Castro-Lacouture, D. BIM-enabled Integrated Optimization Tool for LEED Decisions. In Proceedings of the International Workshop on Computing in Civil Engineering, Austin, TX, USA, 24-27 June 2009; pp. 258-268.

34. Nisbet, N.; Dinesen, B. Constructing the Business Case, Building Information Modelling; British Standards Institution: London, UK, 2010 .

35. Heydarian, A.; Golparvar-Fard, M. A Visual Monitoring Framework for Integrated Productivity and Carbon Footprint Control of Construction Operations. In Proceedings of the International Workshop on Computing in Civil Engineering, Miami, FL, USA, 19-22 June 2011; pp. 504-511.

36. Akhund, M.A.; Memon, A.H.; Ali, T.H.; Memon, N.A.; Kazi, S. Waste Management in Construction Projects of Pakistan. Pak. J. Sci. 2019, 71, 59 .

37. Ali, T.H.; Akhund, M.A.; Memon, N.A.; Memon, A.H.; Imad, H.U.; Khahro, S.H. Application of Artifical Intelligence in Construction Waste Management. In Proceedings of the 2019 8th International Conference on Industrial Technology and Management, ICITM 2019, Cambridge, UK, 2-4 March 2019; pp. 50-55.

38. Ahmad, T.; Thaheem, M.J. Economic sustainability assessment of residential buildings: A dedicated assessment framework and implications for BIM. Sustain. Cities Soc. 2018, 38, 476-491. [CrossRef]

39. Kumar, D.; Raza, M.S.; Ahmed, S.; Siddiqui, F.H. Benefits of Building Information Modelling (BIM) on Green Buildings. In Proceedings of the 5th International Conference on Energy, Environment and Sustainable Development 2018 (EESD 2018), Jamhoro, Pakistan, 14-16 November 2018; pp. 178-189.

40. Gandhi, S.; Jupp, J. Characteristics of Green BIM: Process and Information Management Requirements. In IFIP International Conference on Product Lifecycle Management; Springer: Berlin/Heidelberg, Germany, 2013; pp. 1-11. 
41. Ilhan, B.; Yaman, H. Green building assessment tool (GBAT) for integrated BIM-based design decisions. Autom. Constr. 2016, 70, 26-37. [CrossRef]

42. McGraw Hill Construction. Green BIM: How BIM is Contributing to Green Design and Construction, Bedford, UK; 2010; ISBN 1800591446. Available online: https://www.wbdg.org/files/pdfs/mhc_smartmarket_rep2010.pdf (accessed on 28 September 2020).

43. Maunula, A.; Smeds, R.; Hirvensalo, A. Implementation of Building Information Modeling (BIM)—A process perspective. In Proceedings of the APMS 2008 Innovations in Networks, Espoo, Finland, 14-17 September 2008; pp. 379-386.

44. Park, S.; Kim, I. BIM-Based Quality Control for Safety Issues in the Design and Construction Phases. Int. J. Archit. Res. 2015, 9, 111-129. [CrossRef]

45. Loh, E.; Crosbie, T.; Dawood, N.; Dean, J. A framework and decision support system to increase building life cycle energy performance. J. Inf. Technol. Constr. 2010, 15, 337-353.

46. Wong, K.; Fan, Q. Building information modelling (BIM) for sustainable building design. Facilities 2013, 31, 138-157. [CrossRef]

47. Shoubi, M.V.; Shoubi, M.V.; Bagchi, A.; Barough, A.S. Reducing the operational energy demand in buildings using building information modeling tools and sustainability approaches. Ain Shams Eng. J. 2015, 6, 41-55. [CrossRef]

48. Motawa, I.; Carter, K. Sustainable BIM-based Evaluation of Buildings. Procedia Soc. Behav. Sci. 2013, 74, 419-428. [CrossRef]

49. Lu, K.; Jiang, X.; Tam, V.W.Y.; Li, M.; Wang, H.; Xia, B.; Chen, Q. Development of a Carbon Emissions Analysis Framework Using Building Information Modeling and Life Cycle Assessment for the Construction of Hospital Projects. Sustainability 2019, 11, 6274. [CrossRef]

50. Liang, C.; Wang, Y.; Song, W.; Tan, G.; Li, Y.; Guo, Y. Potential Activity of Recycled Clay Brick in Cement Stabilized Subbase. Appl. Sci. 2019, 9, 5208. [CrossRef]

51. Azeem, S.; Naeem, M.A.; Waheed, A. Adoption of Green Building Practices in Pakistan: Barriers and Measures. In Green Building in Developing Countries; Springer: Cham, Switzerland, 2018.

52. Khalil, W.A.; Gul, S.; Akbar, R.; Owais, S.; Khan, D.A.; Sajid, M.B. Sustainable Residential Buildings in Pakistan: Challenges and Opportunities. In Proceedings of the International Conference of High-Performance Energy Efficient Buildings and Homes (HPEEBH), Lahore, Pakistan, 1-2 August 2018.

53. Somasundaram, S.; Thangavelu, S.R.; Chong, A. Improving building efficiency using Low-E coating based retrofit double glazing with solar films. Appl. Therm. Eng. 2020, 171, 115064. [CrossRef]

54. Alajmi, A.; El-Amer, W. Saving energy by using underfloor-air-distribution (UFAD) system in commercial buildings. Energy Convers. Manag. 2010, 51, 1637-1642. [CrossRef]

55. Peng, C. Calculation of a building's life cycle carbon emissions based on Ecotect and building information modeling. J. Clean. Prod. 2016, 112, 453-465. [CrossRef]

56. Siddiqui, F.; Akhund, M.A.; Ali, T.H.; Khahro, S.H.; Khoso, A.R.; Imad, H.U. Barriers in Adoption of Building Information Modeling in Pakistan's Construction Industry. Indian J. Sci. Technol. 2019, 12, 1-7. [CrossRef] 